Lidija Barjaktarovićc Nikola Stefanović ${ }^{2}$
JEL:G21, 032, G15

DOI:10.5937/industrija47-21347

UDC: $336.71:[004: 007$

005.591.4:336.71(497.11)

Original Scientific Paper

\title{
What is the Effect of Intangible Assets on Earnings of the Serbian Banking Sector? ${ }^{3}$
}

\author{
Article history: \\ Received: 15 January 2019 \\ Sent for revision: 19 January 2019 \\ Received in revised form: 22 March 2019 \\ Accepted: 25 March 2019 \\ Available online: 1 April 2019
}

\begin{abstract}
Digital transformation is the permanent improvement of business processes within a bank by available digital tools and technologies in order to survive in the market. It is driven primarily by the clients' needs, new competitors, regulations, and strategy based on the existing tradition. The aim of the paper is to determine whether there is a link between the money invested in digitalization and the achieved result of the bank through the relevant financial indicators. The results of the research show that the banking offer of alternative distribution channels' products in the Republic of Serbia (RS) follows world trends and it can be considered developed. Furthermore, the level of investment in digitalization has a direct impact on the achieved result of the banking sector. Moreover, the banking sector generates more revenue than traditional products offered, and investments in digitalization, innovation and IT technology are inevitable if they want to survive on the market, which is, due to global trends, the need of clients and requirement of the regulator. It is certainly an imperative for all banks in $R S$ to continue investing in education of employees and clients, improvement of business processes, and new tools in order to survive on the market and be competitive.
\end{abstract}

Keywords: Digitalization, Banking, Digital Transformation, Innovation, Intangible Assets

\footnotetext{
${ }^{1}$ Singidunum University Belgrade, Ibarjaktarovic@singidunum.ac.rs

${ }^{2}$ Singidunum University Belgrade

${ }^{3}$ This research paper was a part of the project no. 47028, in the period 2011-2018, financed by the Serbian Ministry of Science and Technological Development.
} 
Barjaktarović L., Stefanović N.: What is the Effect of Intangible Assets on Earnings of...

\title{
Kakav je efekat nematerijalnih ulaganja na zaradu bankarskog sektora Republike Srbije?
}

\begin{abstract}
Apstrakt: Digitalna transformacija banke je permanentno unapređenje poslovnih procesa i samog opstanka poslovanja banke uz pomoć svih raspoloživih digitalnih alata i tehnologija. Istu pokreću potrebe klijenata, novi konkurenti, regulativa i strategija zasnovana na postojećoj tradiciji. Cilj istraživanja je da utvrdi da li postoji veza između investiranih sredstava u digitalizaciju $i$ ostvarenog rezultata banke kroz prizmu odgovarajućih finansijskih indikatora. Rezultati istraživanja pokazuju da bankarska ponuda proizvoda alternativnih kanala distribucije u Republici Srbiji ide u korak sa okruženjem i svetom, odnosno može se smatrati razvijenom. Dalje, nivo ulaganja u digitalizaciju ima direktan uticaj na ostvareni rezultat bankarskog sektora. Takođe, uočljivo je da bankarski sektor generiše više prihoda od tradicionalnih proizvoda koji nudi a da su ulaganja u digitalizaciju, inovacije $i$ IT tehnologiju neminovnost ukoliko žele da opstanu na tržištu, što zbog globalnih trendova, potreba klijenata i zahteva regulatora. Svakako je imperativ za sve poslovne banke u Republici Srbiji da dalje investiraju u edukaciju zaposlenih i klijenata, unapređenje poslovnih procesa i nove alate kako bi opstale na tržištu i bile konkurentne.
\end{abstract}

Ključne reči: digitalizacija, bankarstvo, digitalna transformacija, inovacija, nematerijalna ulaganja

\section{Introduction}

Digital transformation (of business) is "... organizational change thanks to appliance of digital technology and business model for improving results" (Wade et al., 2016). It means that digital transformation is reorganization and improvement of business processes within a company by available digital tools and technologies in order to survive on the market. Digital transformation is more than the usage of modern technologies and internet tools. It is a flexibility in adapting to changes that never happened faster thanks to the Internet and its benefits.

The digital transformation of banks is driven primarily by the needs of clients, i.e. consumer experience and consumer preferences (Mbama, 2014; Deloitte, 2018). Also, relevant drivers of digitalization of banking operations are new, unregulated players; banking regulation and strategy based on the existing tradition (Krstić \& Tešić, 2016; Omarini, 2017; Omarini, 2018). According to Krstić \& Tešić (2016), the positive changes caused by the digital transformation are: more efficient business models, the acquisition of new 
Barjaktarović L., Stefanović N.: What is the Effect of Intangible Assets on Earnings of...

segments of clients and penetration into new markets, where new services create new sources of revenue.

According to BVA (2015) there were three successive stages in a bank's digitalization process: the first, where new channels and products are developed; the second, featuring adaptation of the technological infrastructure; and the last, involving far-reaching changes in the organization, so as to achieve strategic positioning in the digital environment.

According to EY research (2018) $85 \%$ of global banks considers the implementation of the digital transformation program as a key priority in 2018. Artificial intelligence and advanced analytical techniques will play a key role in the prevention of cyber-attacks and the suppression of new risks that arise and evolve along with technologies and constant changes in market conditions. According to EY (2018) $62 \%$ of global banks expect to be digitally mature in 2020, compared with just 19\% in 2018.

Digitalization of banking operations is a major challenge for all banks in the world (Schmidt et al., 2017). Past studies dealt with the digitalization of banking operations at the strategic level (Nayak, 2018), the prospects of the client (Orstad \& Sonono, 2017; Schmidt et al., 2017; Accenture, 2018; Mylonakis, 2018) the internal perspective of the bank (Cognizant, 2014; KPMG, 2018), by integrating the previous three analyses into multiplestakeholder analysis (Schmidt et al., 2017; Dasho et al., 2016) or potential rewards and losses (Omarini, 2017; Deloitte, 2018: Mbama, 2018).

In the Republic of Serbia, published research results were connected to the importance of electronic and mobile banking in our country (Pavlović \& Mutibarić, 2016; Sanader, 2014), the impact of electronic banking on improving banking services (Mikarić \& Trajković, 2013), development of cash management products (Barjaktarović \& Marković, 2014) and risks in electronic banking (Obradović et al., 2015)

However, according to the authors' findings, there is no research in the Republic of Serbia about the links between the comparability of alternative distribution channels products offer with the world, as well as the fact that intangible investments affect the net result of the banking sector.

The subject of this paper is to assess the results of the digital transformation of the banking sector of Serbia, shown through the alternative distribution channels products offer. The aim of the paper is to determine whether there is a link between the money invested in digitalization and the achieved result through the relevant financial indicators. 
Barjaktarović L., Stefanović N.: What is the Effect of Intangible Assets on Earnings of...

Having in mind the subject and aim of the research, the main hypothesis of research $(\mathrm{H} 1)$ is: the banking offer of alternative distribution channels products in the Republic of Serbia can be considered as developed. An additional hypothesis of the research $(\mathrm{H} 2)$ is: the level of investment in digital transformation has a direct impact on the net result of the Serbian banking sector.

The article consists of four chapters. The first chapter is an introduction to the paper. Within the second chapter of the paper, a methodology is presented. The third chapter of the paper reveals the results of the research. The fourth chapter of the paper represents the conclusion.

\section{Research methodology}

The basis for the research is publicly disclosed data of commercial banks operating in the Republic of Serbia, both on their sites and on the site of the National bank of Serbia (NBS). Considering the fact that the number of banks declined in the analysed period, the survey is based on 27 that operated on March 16, 2019 (NBS, 2019a).

The subject of the analysis is the following banks: Addico Bank a.d. Beograd (which, by the middle of 2016 operated as Hypo Alpe-Adria Bank a.d. Beograd), Agroindustrijsko komercijalna banka AlK a.d. Beograd, Api Bank a.d. Beograd (which, by the middle of October 2018 operated as VTB banka a.d. Beograd), Banca Intesa a.d. Beograd, Bank of China a.d. Srbija, Banka Poštanska štedionica a.d. Beograd, Crédit Agricole banka Srbija a.d. Novi Sad, Direktna banka a.d. Kragujevac (which, by the middle of 2016 operated as KBM banka a.d Kragujevac, and in the past two years it merged with Findomestic a.d. Beograd and Pireaus a.d. Beograd), Erste bank a.d. Novi Sad, Eurobank a.d. Beograd, Expo bank a.d. Beograd (which, by the first half of 2017 operated as Marfin bank a.d. Beograd), Halkbank a.d. Beograd (which, by the second half of 2017 operated as Čačanska banka a.d. Čačak), Jubmes banka a.d. Beograd, Komercijalna banka a.d. Beograd, MIRABANK a.d. Beograd (established in 2015), MTS banka a.d. Beograd (which, by the end of 2014 operated as Dunav banka a.d. Beograd), NLB banka a.d. Beograd, Opportunity banka a.d. Novi Sad, OTP banka Srbija a.d. Novi Sad, ProCredit bank a.d. Beograd, Raiffeisen bank a.d. Beograd, Sberbank Srbija a.d. Beograd (in the second half of 2012 it took over Volksbank a.d. Beograd), Societe Generale banka Srbija a.d. Beograd, Srpska banka a.d. Beograd, 
Barjaktarović L., Stefanović N.: What is the Effect of Intangible Assets on Earnings of...

Telenor banka a.d. Beograd (bought the license of KBC banka a.d. Beograd at the end of 2014), UniCredit bank a.d. Beograd and Vojvođanska banka a.d. Novi Sad.

The time period of the analysis is from 2011 to the third quarter of 2018. The year 2011 was selected as the moment when it was necessary for the Republic of Serbia to switch to Basel Standard II, but it was postponed due to the high level of investment in information technology and education of employees. The result was that the actual implementation of Basel II started on 12/31/2011 instead of 01/01/2011/ (NBS, 2010). Also, the mentioned time period is comparable with analyses in the field of digitalization and contemporary tendencies in the banking sector, which were run by consulting firms all over the world (Deloitte, 2018; Accenture, 2018).

Indicators that are analysed from the balance sheet are the intangible assets and the net result expressed in RSD. The intangible assets are selected as indicators that can be linked to digitalization, innovation, IT (Information Technology) investment, and risk management (in their essence), and because their information was available on the sites of the analysed bank (which meets the requirements of the International Financial Reporting Standards). The intangible assets consist of software, intangible assets under preparation, and licenses. The net result was selected as the key indicator of the business that banks followed in order to demonstrate their success. The key thing for each business bank is to achieve the optimal result, i.e. find the right measure between investment and realized returns; in addition to the field of IT investment and digitization, the focus is on data protection and security of information systems, in order to avoid the reputation risk and consequently unwanted losses. In order to determine the existence of a link between the analysed indicators, non-material investments, and the net results, the correlation coefficient in the software program SPSS was applied.

In this paper, we used the Pearson correlation to determine the connections between intangible assets and net result. The Pearson correlation coefficient is calculated according to the following formula:

$$
r=\frac{\sum_{i=1}^{N}\left(x_{i}-\bar{x}\right)\left(y_{i}-\bar{y}\right)}{\sqrt{\sum_{i=1}^{N}\left(x_{i}-x\right)^{2} \sum_{i=1}^{N}\left(y_{i}-\bar{y}\right)^{2}}}
$$


Barjaktarović L., Stefanović N.: What is the Effect of Intangible Assets on Earnings of...

The elements of formula (Pearson correlation): $\mathrm{N}$ is the number of indicators in the relation; $\mathrm{Xi}$ stands for independent indicators and $\mathrm{Yi}$ for dependent indicators; $\dot{x}$ and $\dot{y}$ are the averages (of relevant indicators). The SPPS software did calculations.

The explanation of Pearson correlation values:

$+/-0-+/-0.2$ no relation

$+/-0.21-+/-0.4$ weak relation

$+/-0.41-+/-0.6$ medium relation

$+/-0.61-+/-0.8$ strong relation

$+/-0.81-+/-1$ very strong relation.

In this research, there are two indicators $(\mathrm{N})$, where the intangible assets are the dependent indicator $(\mathrm{Yi})$, and the net result is the independent indictor (Xi).

\section{Research results and discussion}

In the Republic of Serbia, there is a clear trend of decreasing the number of banks operating. For instance, in 2001 the number amounted to 86 banks, then it was reduced to 34 banks in 2010 (Barjaktarović \& Ječmenica, 2011a), shifting to 27 banks in the first quarter of 2019 (NBS, 2019a), and finally scaling down to 25 in 2019 (the merger of OTP and Vojvodjanska banka, and in the next iteration, the merger of Societe Generale Bank Srbija ad Beograd and OTP Vojvodjanska Group).

Looking at the ownership structure of banks, banks with foreign capital are dominant - 75\%, as of September 30, 2018. If the first five banks in the Republic of Serbia are surveyed (Banca Intesa ad Beograd, UniCredit Bank ad Beograd, Komercijalna banka ad Beograd, Societe General Bank Srbija ad Beograd, and Raiffeisen bank ad Beograd), by the amount of the balance assets, loans placed and deposits collected, they constitute more than a half of the banking sector of the Republic of Serbia (NBS, 2019). However, the concentration level does not affect the level of co-operation in the banking sector (Barjaktarović et al., 2013). The net result of the banking sector has a positive growth trend (RSD 53.9 billion, $0.8 \%$ more than in the same period of 2017) and the profitability indicators are maintained at the same level (NBS, 2019). 
Barjaktarović L., Stefanović N.: What is the Effect of Intangible Assets on Earnings of...

Table 1. An overview of the offer of electronic banking products in the Republic of Serbia (2019)

\begin{tabular}{|l|l|l|l|l|l|}
\hline No & Bank & $\begin{array}{l}\text { E- } \\
\text { banking }\end{array}$ & Cards & More products in offer & $\begin{array}{l}\text { Cash } \\
\text { management } \\
\text { products }\end{array}$ \\
\hline 1. & Addico bank a.d. Beograd & + & + & $\begin{array}{l}\text { Addico Chat Banking } \\
\text { onViber }\end{array}$ & - \\
\hline 2. & AlK banka a.d. Beograd & + & + & - & - \\
\hline 3. & API bank a.m. Beograd & + & + & - & - \\
\hline 4. & $\begin{array}{l}\text { Banca Intesa a.m. } \\
\text { Beograd }\end{array}$ & + & + & - & + \\
\hline 5. & $\begin{array}{l}\text { Banka Posnanski } \\
\text { stedionica a.d. Beograd }\end{array}$ & + & + & - & - \\
\hline 6. & $\begin{array}{l}\text { Bank of China Srbija a.d. } \\
\text { Beograd }\end{array}$ & + & + & - & - \\
\hline 7. & $\begin{array}{l}\text { Credit Agricole banka } \\
\text { Srbija a.d. Novi Sad }\end{array}$ & + & + & - & - \\
\hline 8. & $\begin{array}{l}\text { Direktna banka a.d. } \\
\text { Kragujevac }\end{array}$ & + & + & - & - \\
\hline 9. & Erste bank a.d. Novi Sad & + & + & eBanking Cash credits & + \\
\hline 10. & Expobank a.d. Beograd & + & + & - & - \\
\hline 11. & Eurobank a.d. Beograd & + & + & - & - \\
\hline 12. & Halkbank a.d. Beograd & + & + & - & - \\
\hline 13. & $\begin{array}{l}\text { Jubmes banka a.d. } \\
\text { Beograd }\end{array}$ & + & + & - & - \\
\hline 14. & $\begin{array}{l}\text { Komercijalna banka a.d. } \\
\text { Beograd }\end{array}$ & + & + & $\begin{array}{l}\text { KomBank trader, } \\
\text { KOMeCENTAR, } \\
\text { Distant help }\end{array}$ & - \\
\hline 15. & MIRABANK a.d. Beograd & + & + & - & - \\
\hline 16. & MTS banka a.d. Beograd & + & + & + & - \\
\hline 17. & NLB banka a.d. Beograd & + & + & $\begin{array}{l}\text { e-banking group - } \\
\text { payments within NLB }\end{array}$ & - \\
\hline 18. & $\begin{array}{l}\text { Opportunity banka a.d. } \\
\text { Novi Sad }\end{array}$ & + & + & - & - \\
\hline 19. & $\begin{array}{l}\text { OTP banka Srbija a.d. } \\
\text { Novi Sad }\end{array}$ & + & + & - & - \\
\hline 20. & $\begin{array}{l}\text { ProCredit bank a.d. } \\
\text { Beograd }\end{array}$ & + & + & $24 h$ self service zones & - \\
\hline 21. & $\begin{array}{l}\text { Raiffeisen bank a.d. } \\
\text { Beograd }\end{array}$ & + & + & $\begin{array}{l}\text { REA-electronic } \\
\text { assistant, new } \\
\text { multipurpose ATM, } \\
\text { mobi cash }\end{array}$ & + \\
\hline 22. & Sberbank a.d. Beograd & + & + & Smart cash credits & - \\
\hline 23. & $\begin{array}{l}\text { Societe Generale banka } \\
\text { Srbija a.d. Beograd }\end{array}$ & + & + & - & - \\
\hline 24. & $\begin{array}{l}\text { Srpska banka a.d. } \\
\text { Beograd }\end{array}$ & + & + & - & - \\
\hline 25. & $\begin{array}{l}\text { Telenor banka a.d. } \\
\text { Beograd }\end{array}$ & + & + & Virtual bank & - \\
\hline 26. & $\begin{array}{l}\text { UniCredit bank a.d. } \\
\text { Beograd }\end{array}$ & + & + & - & - \\
\hline & & & & - \\
\hline
\end{tabular}

Source: prepared by the authors on the basis of the data available on the sites of the analysed banks on 03/22/19 and Barjaktarović\& Marković, 2014 
Barjaktarović L., Stefanović N.: What is the Effect of Intangible Assets on Earnings of...

Regardless of the fact that banks invest heavily in IT, innovation, digitalization and risk management, they are only partly transparent information about the offer of alternative distribution channels products. Accordingly, by analysing the sites of banks from the sample, all alternative distribution channels products can be divided into two basic groups (for all segments of clients):

1. Electronic banking (e-banking, m-banking, online banking, home banking, e-commerce, 24/7 payment zones).

2. Payment cards (types: debit and credit - DINA, VISA, Masters, American; POS, ATM, payment method).

Several banks introduced the term digital bank or digital banking. Within the digital bank, the mentioned alternative distribution channels products are listed in Table 1: Addico bank a.d. Belgrade, Erste Bank a.d. Novi Sad, Expobank a.d. Belgrade, Raiffeisen bank a.d. Belgrade, Sberbanka a.d. Belgrade and UniCredit Bank a.d. Belgrade (which even emphasizes the option of e-banking shortcuts on the site itself). A quite wider offer of alternative distribution channels products (1-3) is provided by the following banks:

1.Addico bank a.d. Belgrade - Addico Chat Banking at Viber,

2.Erste Bank a.d. Novi Sad - e-banking cash credits,

3. Komercijalna banka a.d. Belgrade - a) KomBank trader, the application for trading in securities in domestic and foreign markets, b) KOMECENTAR digital branch, c) Distant help - support through the TeamViewer application;

4. NLB Bank - e-banking group - the payment operations within the NLB Group for more favourable conditions for corporates;

5. ProCredit Bank a.d. Belgrade- with $24 \mathrm{~h}$ self-service zones in which the largest number of products can be executed,

6. Raiffeisen bank a.d. Belgrade - the REA-electronic assistant, new multipurpose ATMs, and mobi cache.

7. Sberbanka a.d. Belgrade - smart cash loan.

8. Telenor banka a.d. Belgrade - advertised as a virtual bank for all the products it offers, including the granting of loans.

It is interesting that Societe General Bank a.d. Belgrade, which, in 2015, was the first one which advertised the virtual branch, at the time of the analysis, didn't have this information posted transparently on its site. Moreover, in 2016 Erste Bank a.d. Novi Sad, as a pilot project of the Erste Group, carried out franchising branches, which further reduced costs, and opened up space to invest money in new products that would generate additional revenue for the bank. Also, at the end of 2018, Vojvodjanska banka promoted its virtual banker Voban, but this information is not on the site itself. 
Barjaktarović L., Stefanović N.: What is the Effect of Intangible Assets on Earnings of...

In next step, the authors analysed banks' annual reports and headquarters sites. The conclusion is that four foreign equity owned banks, in addition to the basic ones, partly offer group and special cash management products to corporate clients. Those banks are Banca Intesa a.d. Belgrade, UniCredit Bank a.d. Belgrade, Raiffeisen bank a.d. Belgrade and Erste Bank a.d. Novi Sad (Barjaktarović \& Marković, 2014).

Comparing the banking offer of alternative distribution channels products in the Republic of Serbia with other countries of the world (Deloitte, 2018; Accenture, 2018), it can be noticed that Serbian banking sector is in accordance with it. In this way, $\mathrm{H} 1$ is proved.

In the next step, the intangible investments and the net result of the banking sector were analysed to test $\mathrm{H} 2$. These were the only quantitative publicly disclosed data that would essentially be accompanied by IT, innovation, digitization, and risk management.

Table 2.Correlation coefficient of intangible investments and net results of the banking sector of the Republic of Serbia by years, in the period from 2011 to 3q2018

\begin{tabular}{|c|c|c|c|c|c|c|c|c|}
\hline $\begin{array}{c}\text { Banking } \\
\text { sector }\end{array}$ & $3 q 2018$ & 2017 & 2016 & 2015 & 2014 & 2013 & 2012 & 2011 \\
\hline $\begin{array}{c}\text { Correlation } \\
\text { coefficient }\end{array}$ & 0.6605 & 0.5984 & 0.5265 & 0.4396 & 0.2097 & 0.2490 & 0.5579 & 0.4990 \\
\hline
\end{tabular}

Source: authors' calculations

Further, the comparison of the non-material investment in the Serbian banking sector with the world (Deloitte, 2018), resulted in the conclusion that they are not comparable, as they exclusively contain aggregate categories of software, licenses and intangible investments in preparation (which meets requirement of International Financial Reporting Standards). Thus, it can not be concluded in which technologies and products connected to the digitalization of banks are being invested (and there are no market research that indicates what drives investments and innovations) in the Republic of Serbia. The world invests in artificial intelligence and cognitive computing, analytics, blockchain and internet of things; and investments and innovation are driven by: consumer experience over preferences, regulation, technology portfolio, cybernetic risks and changing labour market habits (Deloitte, 2018). Furthermore, there is a lack of information with internationally active banks' group's financial reports which have leasing companies as their daughter enterprises, what hardware and licenses are in the books of the related parties, and in fact it is in the function of the commercial bank itself. The next limitation in the analysis is that there is no continuity in the number of banks that are the subject of the analysis, and the same is the result of mergers, acquisitions, green-field investments and other legal forms due to the 
Barjaktarović L., Stefanović N.: What is the Effect of Intangible Assets on Earnings of...

liquidation of the state banks (where the deposit portfolio switched to the Postanska Savings Bank) and the sale of domestic private banks (KBC bank - a pilot project on the topic of the license).

The obtained results show that there is a direct relation between the intangible investments and net results, that is, when the value of intangible assets increases - the net result is increased, and vice versa. In this way, $\mathrm{H} 2$ has been proven that the level of investment in digital transformation has a direct impact on the net result of the banking sector of the Republic of Serbia. If we further analyse these indicators by banks, the situation is different.

Table 3 - Correlation coefficient of intangible investments and net result of banks operating in the Republic of Serbia in the period from 2011 to 3q2018

\begin{tabular}{|c|c|c|}
\hline No. & Bank & Correlation coefficient \\
\hline 1. & Addico bank a.d. Beograd & 0.35603 \\
\hline 2. & AlK banka a.d. Beograd & 0.54323 \\
\hline 3. & API bank a.d. Beograd & $(0.02805)$ \\
\hline 4. & Banca Intesa a.d. Beograd & 0.23889 \\
\hline 5. & Banka Postanskastedionica a.d. Beograd & 0.26109 \\
\hline 6. & Bank of China Srbija a.d. Beograd & 1.00000 \\
\hline 7. & Credit Agricolebanka Srbija a.d. Novi Sad & $(0.51206)$ \\
\hline 8. & Direktnabanka a.d.Kragujevac & $(0.19272)$ \\
\hline 9. & Erste bank a.d. Novi Sad & $(0.41934)$ \\
\hline 10. & Expobank a.d. Beograd & $(0.51147)$ \\
\hline 11. & Eurobank a.d. Beograd & 0.029932 \\
\hline 12. & Halkbank a.d. Beograd & 0.657778 \\
\hline 13. & Jubmes banka a.d. Beograd & 0.67536 \\
\hline 14. & Komercijalna banka a.d. Beograd & 0.64342 \\
\hline 15. & MIRABANK a.d. Beograd & $(0.71662)$ \\
\hline 16. & MTS banka a.d. Beograd & 0.00082 \\
\hline 17. & NLB banka a.d. Beograd & 0.44284 \\
\hline 18. & Opportunity banka a.d. Novi Sad & 0.93909 \\
\hline 19. & OTP banka Srbija a.d. Novi Sad & $(0.25209)$ \\
\hline 20. & ProCredit bank a.d. Beograd & 0.06296 \\
\hline 21. & Raiffeisen bank a.d. Beograd & 0.536101 \\
\hline 22. & Sberbank a.d. Beograd & $(0.42323)$ \\
\hline 23. & Societe Generale banka Srbija a.d. Beograd & 0.978464 \\
\hline 24. & Srpska banka a.d. Beograd & $(0.26111)$ \\
\hline 26. & Telenor banka a.d. Beograd & 0.48872 \\
\hline 26. & UniCredit bank a.d. Beograd & 0.68466 \\
\hline 27. & Vovjođanska banka a.d. Novi Sad & 0.28966 \\
\hline
\end{tabular}

Source: authors' calculations

A very strong relation between the indicator intangible investment and the net result exists with the Bank of China, Societe Generale Bank Serbia, and Opportunity Bank. A strong relation between the analysed indicators exists 
Barjaktarović L., Stefanović N.: What is the Effect of Intangible Assets on Earnings of...

with MIRABANK, UniCredit Bank, Jubmes Bank, Halkbank, and Komercijalna Banka. The medium relation between the analysed indicators exists with Raiffeisen Bank, AlK Bank, Credit Agricole Bank Serbia, Telenor Bank, Sberbank, NLB Bank, and Erste Bank. A weak relation between the analysed indicators exists with Banca Intesa, Postanska štedionica, OTP banka, Srpska banka, and Vojvodjanska banka. There is no relation between the indicators analysed with Addico Bank, Api Bank, Direct Bank, Eurobank, MTS Bank, and ProCredit Bank. Based on the values of the correlation coefficient, it can be concluded that the banking sector generates more income than other products it offers, and that investments in digitalization, innovation, and IT technology are inevitable if they want to survive in the market, which is due to global trends, customer needs and regulatory requirements. In addition, banks are forced to optimize their business results and improve the digitization process to invest in various methodologies such as Lean (Riva \& Pilotti, 2017) and Six Sigma (Barjaktarović \& Ječmenica, 2014).

Further analyses of obtained values of the correlation coefficient on the example of the top five Serbian banks, it can be noticed that in the case of: 1) Societe General Bank Serbia ( $4^{\text {th }}$ ranked) - there is a very strong relation between the intangible investments and the net results; 2$)$ UniCredit bank ( $2^{\text {nd }}$ ranked) and Komercijalna banka ( $3^{\text {rd }}$ ranked) - there is strong relation between the intangible investments and the net results; 3 ) Raiffeisen Bank $\left(5^{\text {th }}\right.$ ranked) - there is the medium relation between the intangible investments and the net results; 4) Banca Intesa ( $1^{\text {st }}$ ranked) - there is a poor relation between the intangible investments and the net results. This confirms the previous finding that investments in digitalization, innovation and IT technology are inevitable for survival, but according to the logic of banking operations, the success on the market is the result of an appropriate combination of supply of all products of the bank, established risk management procedures, and asset and liability management system, selling and maintaining business relationships with the existing and new customers.

\section{Conclusions}

The banking offer of alternative distribution channels products in the Republic of Serbia follows world trends and it can be considered developed. Furthermore, the level of investment in digitalization has a direct impact on the achieved result of the banking sector. However, the banking sector generates more revenue than traditional products offered, and investments in digitalization, innovation and IT technology are inevitable if they want to survive on the market, which is due to the global trends, the need of clients and requirement of the regulator. 
Barjaktarović L., Stefanović N.: What is the Effect of Intangible Assets on Earnings of...

The base for future research is to conduct a survey through the Association of Serbian Banks with commercial banks in which technology and products are invested, how it is financed, how the indicators of the success of the projects themselves, which indicators are relevant for which bank (e.g. ROI, yield / investment, NPV, etc.), how many new products and for what time generates revenue, what time is necessary for introducing a new product and achieving satisfactory profitability (for that specific product), how market analyses are made before and after the introduction of a new product belonging to the group of alternative distributions, how to monitor the effects of cross-selling products with alternative channels of distribution, and finally how management methodologies are applied (such as Kaizen, Lean, Six Sigma, Lean Six Sigma, etc.) contribute to further digitization and innovation in the bank's business.

It is certainly imperative for all commercial banks in the Republic of Serbia to continue investing in education of employees and clients, improvement of business processes and new tools in order to survive on the market and be competitive.

\section{References}

Accenture consulting. (2018). Hello you: Transforming the customer conversation in financial services. Retrieved from: https://www.accenture.com/t00010101T000000Z_w___gb-en/_acnmedia/PDF80/Accenture-Hello-You.pdf

Addico Bank a.d. Beograd. (2019). Digital Banking. Retrieved from http: https://www.addiko.rs/

Agoindustrijskokomercijalnabanka AlK a.d. Beograd. (2019). Electronic banking. Retrieved from https: www.aikbanka.rs/poljoprivreda/elektronsko-bankarstvo

Api Bank a.d. Beograd. (2019). E-banking. Retrieved from https:// www.apibank.rs/elektronsko-bankarstvo/

Banca Intesa a.d. Beograd. (2019). E-banking. Retrieved from https://www.bancaintesa.rs/stanovnistvo/elektronsko-bankarstvo.28.html

Bank of China a.d.Srbija. (2019). Online Banking. Retrieved from:http://www.bankofchina.com/rs/

Banka Poštanskaštedionicaa.d. Beograd. (2019). Electronic Banking. Retrieved from:https://www.posted.co.rs

Barjaktarović, L., \&Ječmenica D. (2011). Primenakonceptašest sigma u bankarstvu. Bankarstvo, 1-2, 30-45.

Barjaktarović, L., \&Ječmenica D. (2011a). Optimizam vs pesimizamkonkurentnosti bankarskogsektoraSrbije. Industrija, 2, 137-150.

Barjaktarović, L., Filipović, \& S. Dimić, M. (2013). Concentration level of banking industry in CEE countires/ndustrija, 41 (3), 39-53. doi: 10.5937/industrija41-4712

Barjaktarović, L., \&Marković, M. (2014). Razvoj Cash Management proizvoda u Srbiji i uticajna profitabilnost banaka. Bankarstvo, 5, 48-69. 
Barjaktarović L., Stefanović N.: What is the Effect of Intangible Assets on Earnings of...

BVA research. (2015). Digital Economy Watch: DIGITAL ECONOMY - The digital transformation of the banking industry. Retrieved from:https://www.bbvaresearch.com/en/category/themes/digital-economy/

Cognizant. (2014). Digital Banking: Enhancing Customer Experience; Generating Long-Term Loyalty. Retrieved from:https://www.cognizant.com/InsightsWhitepapers/Digital-Banking-EnhancingCustomer-Experience-Generating-Long-Term-Loyalty.pdf

Crédit Agricole banka Srbija a.d. Novi Sad. (2019). Electronic Banking. Retrieved from:https://www.creditagricole.rs/elektronsko-bankarstvo/elektronskobankarstvo.144.html

Dasho, A., Meka, E., Sharko, G., \&Baholli, I. (2016, June). Digital Banking the Wave of the Future. Paper presented at the $7^{\text {th }}$ International Conference organized by the department of statistics and applied informatics of the Faculty of Economy, University of Tirana, in Tirana. Retrieved from: https://www.researchgate.net/publication/315706647

Deloitte. (2018). 2018 FEBRABAN Banking Technology Survey. Retrieved from: https://www2.deloitte.com/content/dam/Deloitte/br/Documents/financialservices/2018-FEBRABAN-BankingTecnhology-Survey.pdf

Direktnabankaa.d.Kragujevac. (2019). E-banking. Retrieved from: https://www.direktnabanka.rs/privreda/e-banking/

Erste bank a.d. Novi Sad. (2019). Digital Banking. Retrieved from: https://www.erstebank.rs/sr/Stanovnistvo

Eurobanka.d. Beograd. (2019). Digital Banking. Retrieved from:www.eurobank.rs/digitalno-bankarstvo/e-banking---eurobank.1739.html

Expo bank a.d. Beograd. (2019). e-Banking. Retrieved from:http://www.expobank.rs/index.php/sr/ebanking

EY. (2018).Global banking outlook 2018: Pivoting toward an innovation-led strategy. Retrieved from:https://www.ey.com/Publication/vwLUAssets/ey-global-bankingoutlook-2018/\$File/ey-global-banking-outlook-2018.pdf

Halkbanka.d. Beograd. (2019). Electronic Banking. Retrieved from http://http://www.halkbank.rs/opste-informaciie-e-bank.nspx

Jubmesbankaa.d. Beograd. (2019). E-banking. Retrieved from: http://http://www.jubmes.rs/code/navigate.asp?ld=511

Komercijalnabankaa.d. Beograd. (2019). E-services. Retrieved from: https:///www.kombank.com/sr/e-servisi]

Krstić, N., \&Tešić, D. (2016). Digitalnatransformacijabankarskogposlovanja opsanostiliprilika? Bankarstvo, 2, 12-33. doi: 10.5937/bankarstvo1602012K

KPMG (2018) Banking Systems Survey 2017/2018: Technology challenges for Dutch banks in the digital era. Retrieved from: https://assets.kpmg/content/dam/ $\mathrm{kpmg} / \mathrm{nl} / \mathrm{pdf} / 2018 /$ sector/banken/banking-systems-survey-20172018.pdf

Mylonakis, J. (2018). Digital Transformation of the Greek Retail Banking: An Evaluation of Systemic Banks' Websites, Business Management and Strategy, 9 (2), 117-128. doi:10.5296/bms.v9i2.14100

Mbama, C. (2018). Digital banking, customer experience and bank financial performance: UK customers' perceptions. International Journal of Bank Marketing, 36 (2), 230-255. Retrived from: http://shura.shu.ac.uk/15903/

Mikarić, B., \&Trajković, M. (2013). Uticaj elektronskog poslovanja na poboljšanje usluga u bankarstvu. Trendovi u poslovanju,2 (2/2013), 69-79. 
Barjaktarović L., Stefanović N.: What is the Effect of Intangible Assets on Earnings of...

MIRABANK a.d. Beograd. (2019). E-banking. Retrieved from: https://www.mirabankserbia.com/what-we-offer/executive-banking/e-banking

MTS bankaa.d. Beograd. (2019). mBanking. Retrieved from: https:// mtsbanka.rs/srLatn-RS/stanovnistvo/mBanking

Nayak. R. (2018). A Conceptual Study on Digitalization of Banking - Issues and Challenges in Rural India. International Journal of Management, IT \& Engineering, 8(6), 186-191.

National Bank of Serbia - NBS. (2011). Bankarskisektor u Srbiji: Izveštajza IV tromesečje 2010.godine. Retrieved from:http://www.nbs.rs/internet/cirilica/55/index.html

National Bank of Serbia - NBS. (2019). Bankarskisektor u Srbiji: Izveštajza III tromesečje 2018.godine. Retrievedfrom: http://www.nbs.rs/internet/cirilica/55/index.html

National Bank of Serbia - NBS. (2019a). Bankarskisistem/Spisakbanaka. Retrieved from: http://www.nbs.rs/internet/cirilica/50/50_2.html

NLB bankaa.d. Beograd. (2019). Corporate.Retrieved from: https://www.nlb.rs/strana/16421/privreda

Obradović, J., Dragosavac, M., \&Arsić, S. (2015, April). The use of modern techniologies in banking: abuse and possible soklutions. Paper presented at the Synthesis Conference organized by Singidunum University, Belgrade. Retrieved from: http://portal.sinteza.singidunum.ac.rs/issue/showAll/2015

Omarini, A. (2017). The Digital Transformation in Banking and The Role of FinTechs in the New Financial Intermediation Scenario. International Finance, Economics and Trade. 1(1), 1-6.

Omarini A. (2018). Banks and Fintechs: How to Develop a Digital Open Banking Approach for the Bank's Future. International Business Research, 11 (9), 23-36.

Opportunity bankaa.d. Novi Sad. (2019). E-banking. Retrieved from: http://http://www.obs.rs/biznis/elektronsko-bankarstvo/

OTP bankaSrbijaa.d. Novi Sad. (2019). Electronic Banking. Retrieved from:https:// www.otpbanka.rs/elektronsko-bankarstvo

Orstad, R., \&Sonono, B. (2017). The Effects of the Digital Transformation Process on Banks' Relationship with Customers - Case Study of a Large Swedish Bank (Master thesis, Upsala University Sweden). Retrieved from: http://uu.divaportal.org/smash/record.jsf?pid=diva2\%3A1115984\&dswid=_e_12s3

Pavlović, M., \&Mutibarić, J. (2016). Značaj i primenaelektronskogbankarstva u RepubliciSrbiji Vojnodelo, 2, 242-262. doi: 10.5937/vojnodelo16021242P

ProCreditbanka.d.Beograd. (2019). Business. Retrievedfrom: https://www.procreditbank.rs/index.php/sr/biznis/elektronsko-bankarstvo/internetbankarstvo

Raiffeisenbanka.d.Beograd. (2019). Digital Banking. Retrievedfrom: https://www.raiffeisenbank.rs

Riva A., \&Pilotti L. (2017). Digital and lean transformation in the bank and in the financial services: the experience of UniCredit Bank. International Journal of Management Research and Business Strategy. Article accepted for publication in the press process. Retrieved from: https://www.researchgate.net/publication/323336977

Sanader, D. (2014). Mobilnobankarstvo: novi trend u savremenombankarskom sektoru. Bankarstvo, 5, 86-109. 
Barjaktarović L., Stefanović N.: What is the Effect of Intangible Assets on Earnings of...

SberbankSrbijaa.d. Beograd. (2019). Digital Banking. Retrieved from: https://www.sberbank.rs/stanovnistvo

Schmidt, J., Drews, P., \&Schirmer, I. (2017, August). Digitalization of the Banking Industry: A Multiple Stakeholder Analysis on Strategic Alignment. Paper presented at the $23^{\text {rd }}$ Americas Conference on Information Systems organized by Association Information Systems in Boston. Retrieved from: https://www.researchgate.net/publication/319103682

Schmidt, J., Drews, P., \&Schirmer, I. (2016, August). End-users' perspective on digitalization: A study on work order processing in the German banking industry. Paper presented at the $22^{\text {nd }}$ Americas Conference on Information Systems organized by Association Information Systems in San Diego. Retrieved from: https://www.researchgate.net/publication/301700202

SocieteGeneralebankaSrbijaa.d. Beograd (2019) Business [internet site: https:// www.societegenerale.rs/privreda/elektronsko-bankarstvo-privreda/]

Srpskabankaa.d. Beograd (2019) E-banking [internet site: http:// http://www.srpskabanka.rs/e-bankarstvo/index.html]

Telenor bankaa.d. Beograd. (2019). Online Banking. Retrieved from: http:// online.telenorbanka.rs/Identity/

UniCredit bank a.d. Beograd. (2019). Bank on the button. Retrieved from: https:// nadugme.unicreditbank.rs/korak-po-korak-vodic/korak-po-korakvodic.19.html\#Online zahtevi

Vojvođanskabankaa.d. Novi Sad. (2019). E-bank. Retrieved from: https://www.voban.rs/e-banking

Wade, M., Macaulay, J., Nornonha, A., \&Barbier, J. (2016). Orchestringtransformation: how to deliver winning performance with a connected approach to change. Lausanne, Switzerland: Global centre for digital business transformation. 